\title{
Astana al-Nursari: The Comparison with Type of Banjar Traditional Architecture
}

\author{
Muhammad Deddy Huzairina ${ }^{1, *}$ and Anna Oktaviana ${ }^{1}$ \\ ${ }^{1}$ Faculty of Engineering, Lambung Mangkurat University, Banjarmasin, Indonesia
}

\begin{abstract}
The formulation and it's examination of Banjar traditional arschitecture was based of sample of house that belonging to Banjar merchant, whereas part of it's type are the building in Banjar Kingdom Palace. Astana Al-Nurasri in Kotawaringin in Central Kalimantan has strong relation to the Bajarese Kingdom Palace and it's culture and it 's never been used to formulate Banjar traditional architecture. Because of that, the main objectives of the research are: to compare Astana Al-Nursari with type of Banjar traditional architecture by some of variable, and to enrich formulation of typology and morphology of Banjar traditional architecture. There are a little compatibility if the analysis is based on physical variables, such as: plan form, building form, proportion and ornament. But the philosophy and design concept have compatibility. First, the room and it's order. Second, philosophy of dimension and high proportion that cover the room inside. Third, the number of windows equal to each room. Forth, each of mass in Astana Al-Nursari has form combination tha reflect what kind of room inside.
\end{abstract}

Keywords: Astana Al-Nursari, Banjar traditional architecture, typology, comparation.

\section{Introduction}

The type of Banjar traditional architecture has been formulated by Saleh (1983) and Seman (1982), which has alittle differences. The formulation has been developed by Prodi Arsitektur ULM since 2004, that scrutinize the scientific foundation. At least 7 research have been done. The research by Prodi Arsitektur ULM have 2 main objectives, i.e.: 1). To conserve and preserve the last Banjar traditional houses by comprehensif grafic data and photo, 2). To develop and strengthen typology and morphology of Banjar traditional architecture.

Typology of Banjar traditional architecture that has been developed since 1982 to 2009 used sample from houses that built by the Banjar merchant. None of the sample is from the building in Banjar Kingdom Palace. The buildings in Banjar Kingdom Palace has been destroyed by Dutch in 18th century.

\footnotetext{
* Corresponding author: deddyhuz@yahoo.com
} 
"Astana Al-Nursari" that was built between 1817 to 1855 , is located in Kotawaringin Lama Province of Central Kalimantan (+/- $700 \mathrm{Km}$ west of Banjarmasin), has similar form with Bubungan Tinggi (it is one of the type of Banjar traditional architecture).

This building is one of the buildings in Kotawaringin Kingdom Palace area. Kotawaringin Kingdom was established in 1637 by the first king Pangeran Dipati Anta Kusuma which is the son of Marhum Panembahan or Sultan Mustainbullah, the $4^{\text {th }}$ Banjar king. The language and building culture that developed in Kotawaringin is origined from Banjar Kingdom (Pemkab Kotawaringin Barat:2001).

Astana Al-Nursari has strong relation to the culture and history of Banjar Kingdom architecture. Because of that, the building is precious sample to enrich research of typology and morphology of Banjar traditional architecture.

The main objectives of the research are:

a. To get the comprehensif grafic data and photo of cultural conservation building of Astana Al-Nursari.

b. To compare Astana Al-Nursari with type of Banjar traditional architecture by some of variable.

\section{Methodology}

The work plan and methods used for this research proposal are as follows:

a. The research is preceded by the preparatory phase, which contains: the creation of a complete work plan and literature review.

b. Comprehensive and detailed measurements and photoshoots of Astana Al-Nursari.

- Measurements are done by meter.

- Shoot / video with digital cameras and drones.

- Documented sections are: entire building, up to structure and construction.

c. Collection of research materials ever done (measurement results, pictures, photos and writing).

- Measurement results, in the form of: site situation, floor plans, looks, pieces, and building details.

- Photos and writings, are needed to complement the deficiencies not found in the measurement results. Generally associated with detail ornaments and photos / posts about the details of certain parts of the building.

d. Interview with related parties, especially regarding the original form of the building of the fort.

Interview method is a guided interview, where the required data framework is included and scrutinized by direct interview.

Interviewees were:

- People and local community.

- Parties who have conducted research on the building.

e. The depiction of the results of measurement of research objects into 2D AutoCad and 3D SketchUp form. This description is based on:

- Results of measurement and shooting / video in the field completely.

- Results of research ever undertaken.

f. Analysis by comparing the object of study with traditional Banjar architectural typology, with several variables: the floor plan, the shape of the roof, the proportion of the floor plan, the visible proportions, the number and position of the doors and windows, the number of columns, and ornaments. 
g. Analysis of the concept and philosophy of Astana Al-Nursari building with the concept and philosophy of building on traditional architecture typology of Banjar.

\section{Banjar Traditional Architecture}

The traditional architecture in South Kalimantan Province is very diverse, which can be distinguished by the tribal groups that built it.

Banjar traditional architecture is established by Suku Banjar, that is developed in the interval of time. The range of this interval can not be determined, especially the beginning period.

Banjar traditional architecture is the cultural product of Suku Banjar that is probably has form evolution until the form that eksist nowadays. That is strong indication that the elements of Banjar traditional architecture was performed by some of cultural ethnics that built the whole Banjar cultural.

Some of Banjar traditional architecture (houses and mosques) are still eksist, spread in several location in South Kalimantan. The locations generally are the central activity of ancient settlement. Since 1945 to 1960 until nowadays Banjar traditional architecture is not used anymore as the concept in building houses and mosques (Huzairin:2005).

The references used regarding to Banjar traditional architecture until 2005 are the type established by M. Idwar Saleh and Syamsiar Seman. The formulated typology by 2 writer is tend to focus to form aspect (plan form, building shape, and the detail elements)

The typology established by M. Idwar Saleh (1983) and Syamsiar Seman (1982) divide Banjar traditional architecture to 13 types, i.e.:

1. Rumah Bubungan Tinggi.

2. Rumah Gajah Baliku.

3. Rumah Gajah Manyusu.

4. Rumah Palimasan.

5. Rumah Palimbangan.

6. Rumah Balai Bini.

7. Rumah Balai Laki.
8. Rumah Tadah Alas.

9. Rumah Cacak Burung atau Anjung Surung.

10. Rumah Joglo.

11. Rumah Bangun Gudang.

12. Rumah Cara Obos.

13. Rumah Lanting.

\section{Further Study of Banjar Traditional Architecture}

In order to explore the background as well as testing the typology that Saleh (1983) and Seman (1982) have produced, it began in 2002 the author conducted a series of related studies.

In 2004, a comprehensive inventory of traditional houses located in the Jingah River area, which is home to the traditional houses still remaining in Banjarmasin, has received 12 samples of traditional houses inventoried (Huzairin: 2004).

In 2006 re-conducted research that aims to get the typology and morphology of Banjar traditional house based on the population found in North Banjarmasin. North Banjarmasin was chosen because in this kecamatan centered relics of traditional houses of Banjar, beside this area is center of old kingdom of Banjar. Based on field identification in the study area there are 45 sample populations that meet the criteria. Due to the limited time and cost, then selected a sample of 28 houses. However, the remaining 17 partially selected houses are already represented in the 28 samples, and others are severely damaged (Huzairin: 2006).

Variables used for the formulation of typology are 9 variables, namely: the shape of the plan \& space, the shape of the terrace, the form of stairs, the shape of the roof, the proportion of the floor plan, the proportion of looks, the number of doors and windows, the 
number of rows of columns, and ornaments. If all the variables are linked to each other, then there will be a combined typology of 27 types or almost equal to the number of samples (28 samples). Therefore, when connecting all variables can be said there is no regularity (Huzairin: 2006).

In the formulation of the 2 variables combined only 4 variables (indicated to be the basis of typology Saleh (1983) and Seman (2001)), namely the shape of the plan and space, the shape of the terrace, the shape of the stairs, and the shape of the roof. Typology analysis of these 4 variables yielded 19 types with the combination of results shown in the following table (Huzairin: 2006).

Table 1. Typology of case studies based on 4 variables and explanations.

\begin{tabular}{|c|c|c|c|c|c|}
\hline No & Tipe & \multicolumn{4}{|c|}{ Variable Typology } \\
\hline & & $\begin{array}{l}\text { Shape } \\
\text { Plan }\end{array}$ & Terrace & Stairs & Roof Shape \\
\hline 1 & $\begin{array}{l}\text { Tipe } 01 \\
\text { (1 sampel) }\end{array}$ & Cross & Full Terrace & Stairs in the middle & Bubungan Tinggi \\
\hline 2 & $\begin{array}{l}\text { Tipe } 02 \\
\text { (1 sampel) }\end{array}$ & Cross & Full Terrace & Stairs in the middle & Gajah Baliku \\
\hline 3 & $\begin{array}{l}\text { Tipe } 03 \\
\text { (7 sampel) }\end{array}$ & Cross & Full Terrace & Stairs in the middle & Balai Bini \\
\hline 4 & $\begin{array}{l}\text { Tipe } 04 \\
\text { (1 sampel) }\end{array}$ & Cross & Full Terrace & Stairs in the middle & Cacak Burung (modif) \\
\hline 5 & $\begin{array}{l}\text { Tipe } 05 \\
\text { (1 sampel) }\end{array}$ & Cross & Full Terrace & Stairs in the middle & Tadah Alas (modif) \\
\hline 6 & $\begin{array}{l}\text { Tipe } 06 \\
\text { (1 sampel) }\end{array}$ & Cross & Full Terrace & $\begin{array}{l}\text { Stairs in the middle } \\
\text { (side directions) }\end{array}$ & Balai Bini \\
\hline 7 & $\begin{array}{l}\text { Tipe } 07 \\
\text { (1 sampel) }\end{array}$ & Cross & Full Terrace & Stairs on the side & $\begin{array}{l}\text { Cacak Burung/ Tadah } \\
\text { Alas/ Gajah Manyusu }\end{array}$ \\
\hline 8 & $\begin{array}{l}\text { Tipe } \mathbf{0 8} \\
\text { (1 sampel) }\end{array}$ & Cross & Half Terrace & Stairs on the side & Tadah Alas (modif) \\
\hline 9 & $\begin{array}{l}\text { Tipe } 09 \\
\text { (1 sampel) }\end{array}$ & Cross & No Terrace & Stairs in the middle & Bubungan Tinggi \\
\hline 10 & $\begin{array}{l}\text { Tipe 10 } \\
\text { (3 sampel) }\end{array}$ & Rectangle & Full Terrace & Stairs in the middle & Palimasan \\
\hline 11 & $\begin{array}{l}\text { Tipe } 11 \\
\text { (1 sampel) }\end{array}$ & Rectangle & Full Terrace & Stairs in the middle & Palimbangan (modif) \\
\hline 12 & $\begin{array}{l}\text { Tipe } 12 \\
\text { (1 sampel) }\end{array}$ & Rectangle & Full Terrace & Stairs in the middle & Joglo \\
\hline 13 & $\begin{array}{l}\text { Tipe } 13 \\
\text { (1 sampel) }\end{array}$ & Rectangle & Full Terrace & $\begin{array}{l}\text { Stairs in the middle } \\
\text { (side directions) }\end{array}$ & Palimasan \\
\hline 14 & $\begin{array}{l}\text { Tipe } 14 \\
\text { (2 sampel) }\end{array}$ & Rectangle & Half Terrace & Stairs on the side & Palimasan (modif) \\
\hline 15 & $\begin{array}{l}\text { Tipe } 15 \\
\text { (1 sampel) }\end{array}$ & Rectangle & Half Terrace & Stairs on the side & Model Baru 1 \\
\hline 16 & $\begin{array}{l}\text { Tipe } 16 \\
\text { (1 sampel) }\end{array}$ & Rectangle & $\begin{array}{l}\text { A third } \\
\text { terrace }\end{array}$ & Stairs in the middle & Palimasan (modif) \\
\hline 17 & $\begin{array}{l}\text { Tipe } 17 \\
\text { (1 sampel) }\end{array}$ & Rectangle & $\begin{array}{l}\text { A third } \\
\text { terrace }\end{array}$ & Stairs in the middle & Model Baru 2 \\
\hline 18 & $\begin{array}{l}\text { Tipe } 18 \\
\text { (1 sampel) }\end{array}$ & Rectangle & $\begin{array}{l}\text { One and Half } \\
\text { Terrace }\end{array}$ & $\begin{array}{l}\text { Stairs in the middle } \\
\text { (side directions) }\end{array}$ & Palimasan (modif) \\
\hline 19 & $\begin{array}{l}\text { Tipe } 19 \\
\text { (1 sampel) }\end{array}$ & Rectangle & No Terrace & Stairs on the side & $\begin{array}{l}\text { Palimbangan/ Cacak } \\
\text { Burung }\end{array}$ \\
\hline
\end{tabular}

Source: Huzairin,2006 
In 2006 the same research was conducted in order to find the typology and morphology of Banjar traditional house, but the sample location in Marabahan city ( $\pm 40 \mathrm{~km}$ from Banjarmasin), which is the city of Daha Kingdom (before Banjar Kingdom), and there are still many houses traditional Banjar which is quite old age.

From this research based on 15 samples with 7 variables (building orientation, floor plan, roof shape, number and position of door \& window, proportion, shape and proportion of front view, and ornament pattern), there are 9 types of houses (Penenliti Architecture Team UNLAM: 2006).

In $2009 \&$ 2010, Banjar Traditional Architecture related to the structure and construction was conducted. The formulation of typology and structure morphology and construction of Banjar traditional house is based on 20 samples, spread its location in 3 different areas (Banjarmasin, Marabahan, and Martapura). From the results of the research, it is found a regularity in terms of: structural and construction systems, connection systems between structural elements, and dimensions.

\section{General Description Of Astana Al-Nursari}

Astana Al-Nursari has the total length of $51,45 \mathrm{M}$ and the total wide of 25,78 M. The dominant roof shape is Bubungan Tinggi, whereas the highest roof from the ground is $15,40 \mathrm{M}$.

Research's object consist of 4 building that connect one to each other by the narrow room. The four buildings have different form one to each other, nevertheless have similarity in: building material, dimention and the order of the column, the pattern of wall panel, and structure system. 

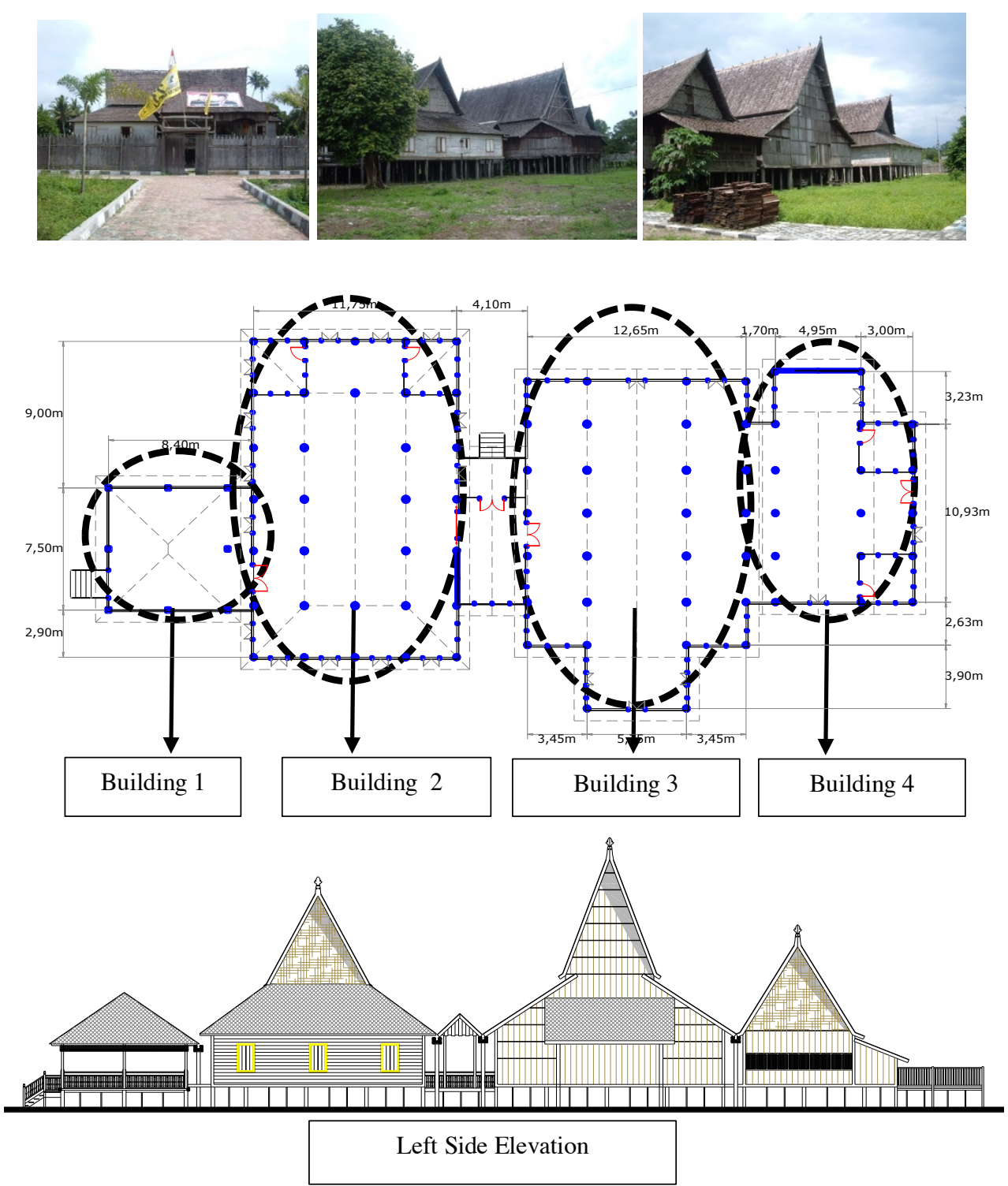

Fig. 1. Photos, floor plans and side view Astana Al-Nursari.

The four buildings are:

1. Building 1: pendopo, the form of Palimasan.

2. Building 2: living room and multipurpose, the combination form of Palimasan and Bubungan Tinggi.

3. Building 3: family room \& anjung (bed room), the form of Bubungan Tinggi.

4. Building 4:kitchen, the form of Bubungan Tinggi. 


\section{Comparation of Astana al-Nursari with Typology of Banjar Traditional Architecture}

The comparation are based onsome variables, i.e.: the shape of plan and room, the shape of roof, plan proportion, elevation proportion, the number and position of windows, the number and order of columns, and ornament.

The whole research object is not shown the similarity of all type of Banjar traditional architecture. But if it is separated by each 4 mass, there are any of similarity.

The comparation analysis is resumed in the table below.

Tabel 2. The comparation of Astana Al-Nursari with typology of Banjar traditional architecture.

\begin{tabular}{|c|c|c|c|c|c|}
\hline No & Variabel & Building 1 & Building 2 & Building 3 & Building 4 \\
\hline 1 & $\begin{array}{l}\text { The shape } \\
\text { of plan }\end{array}$ & $\begin{array}{l}\text { The shape of } \\
\text { plan is tend to } \\
\text { rectangle } \\
\text { compare to } \\
\text { quadrangle }\end{array}$ & $\begin{array}{l}\text { The both shape of } \\
\text { plan is } \\
\text { quadrangle, but } \\
\text { the orientation is } \\
\text { different }\end{array}$ & $\begin{array}{l}\text { The shape of plan } \\
\text { is uncomplete } \\
\text { cross }\end{array}$ & $\begin{array}{l}\text { The shape of } \\
\text { plan is } \\
\text { uncomplete } \\
\text { cross }\end{array}$ \\
\hline 2 & Room order & $\begin{array}{l}\text { One room } \\
\text { compare to at } \\
\text { least } 3 \text { rooms }\end{array}$ & $\begin{array}{l}\text { One main room } \\
\text { compare to at } \\
\text { least } 3 \text { rooms }\end{array}$ & $\begin{array}{l}\text { There are } 4 \\
\text { rooms, but the } \\
\text { order is different } \\
\text { from the one of } \\
\text { type of Bubungan } \\
\text { Tinggi }\end{array}$ & $\begin{array}{l}\text { There are only } 2 \\
\text { rooms }\end{array}$ \\
\hline 3 & $\begin{array}{l}\text { The shape } \\
\text { of roof }\end{array}$ & $\begin{array}{l}\text { Type of } \\
\text { Palimasan }\end{array}$ & $\begin{array}{l}\text { Combination of } \\
\text { Type of } \\
\text { Palimasan and } \\
\text { Type of } \\
\text { Bubungan Tinggi }\end{array}$ & $\begin{array}{l}\text { Type of } \\
\text { Bubungan Tinggi }\end{array}$ & $\begin{array}{l}\text { Type of } \\
\text { Bubungan } \\
\text { Tinggi }\end{array}$ \\
\hline 4 & $\begin{array}{l}\text { Plan } \\
\text { proportion }\end{array}$ & $\begin{array}{l}\text { There are not } \\
\text { appropriate } \\
\text { proportion }\end{array}$ & $\begin{array}{l}\text { There are not } \\
\text { appropriate } \\
\text { proportion }\end{array}$ & $\begin{array}{l}\text { The closed room } \\
\text { with many } \\
\text { windows. First } \\
\text { door is the main } \\
\text { entrance to the } \\
\text { room, the second } \\
\text { room connect to } \\
\text { palidangan } \\
\text { (family room) } \\
\text { There are not } \\
\text { appropriate } \\
\text { proportion. Unless } \\
\text { the ratio of width } \\
\text { to length of } \\
\text { anjung that is } \\
0,65 \text {. The same } \\
\text { ratio in Banjar } \\
\text { traditional } \\
\text { architecture is } \\
\text { from } 0,50 \text { to } 0,60\end{array}$ & $\begin{array}{l}\text { There are not } \\
\text { appropriate } \\
\text { proportion. } \\
\text { Unless the ratio } \\
\text { of width to } \\
\text { length of anjung } \\
\text { that is } 0,65 \text {. The } \\
\text { same ratio in } \\
\text { Banjar } \\
\text { traditional } \\
\text { architecture is } \\
\text { from } 0,50 \text { to } \\
0,60\end{array}$ \\
\hline
\end{tabular}




\begin{tabular}{|c|c|c|c|c|c|}
\hline No & Variabel & Building 1 & Building 2 & Building 3 & Building 4 \\
\hline 5 & $\begin{array}{l}\text { Elevation } \\
\text { proportion }\end{array}$ & $\begin{array}{l}\text { There are not } \\
\text { appropriate } \\
\text { proportion }\end{array}$ & $\begin{array}{l}\text { There are not } \\
\text { appropriate } \\
\text { proportion }\end{array}$ & $\begin{array}{l}\text { There are not } \\
\text { appropriate } \\
\text { proportion }\end{array}$ & $\begin{array}{l}\text { There are not } \\
\text { appropriate } \\
\text { proportion }\end{array}$ \\
\hline 6 & $\begin{array}{l}\text { The number } \\
\& \text { position } \\
\text { of doors \& } \\
\text { windows }\end{array}$ & $\begin{array}{l}\text { There is no } \\
\text { wall. It is the } \\
\text { open airy } \\
\text { room }\end{array}$ & $\begin{array}{l}\text { The closed room } \\
\text { with many } \\
\text { windows. First } \\
\text { door is the main } \\
\text { entrance to the } \\
\text { room, the second } \\
\text { room connect to } \\
\text { palidangan } \\
\text { (family room) }\end{array}$ & $\begin{array}{l}\text { The closed room } \\
\text { with few } \\
\text { windows, so the } \\
\text { room is quite } \\
\text { dark. First door is } \\
\text { the entrance to the } \\
\text { room, the second } \\
\text { room connect to } \\
\text { pedapuran } \\
\text { (kitchen) }\end{array}$ & $\begin{array}{l}\text { The closed } \\
\text { room with few } \\
\text { windows, so the } \\
\text { room is quite } \\
\text { dark. First door } \\
\text { is the entrance } \\
\text { to the room, the } \\
\text { second room } \\
\text { connect to back } \\
\text { terrace. }\end{array}$ \\
\hline 7 & $\begin{array}{l}\text { Columns } \\
\text { order }\end{array}$ & $\begin{array}{l}\text { Distance } \\
\text { between } \\
\text { column is } \\
\text { same: } 1,25 \text { to } \\
1,60 \mathrm{~m}\end{array}$ & $\begin{array}{l}\text { Distance between } \\
\text { column is same: } \\
1,25 \text { to } 1,60 \mathrm{~m}\end{array}$ & $\begin{array}{l}\text { Distance between } \\
\text { column is same: } \\
1,25 \text { to } 1,60 \mathrm{~m}\end{array}$ & $\begin{array}{l}\text { Distance } \\
\text { between column } \\
\text { is same: } 1,25 \text { to } \\
1,60 \mathrm{~m}\end{array}$ \\
\hline 8 & Ornament & $\begin{array}{l}\text { The fence use } \\
\text { rasi (iron), as } \\
\text { commonly } \\
\text { used in the } \\
\text { house of } \\
\text { Banjar } \\
\text { traditional } \\
\text { architecture. } \\
\text { On the stair } \\
\text { column has } \\
\text { tne carved } \\
\text { column head. } \\
\text { The carved } \\
\text { that is above } \\
\text { the fence and } \\
\text { below plafond } \\
\text { has same } \\
\text { position and } \\
\text { shape with } 1 \\
\text { to } 2 \text { sample in } \\
\text { Banjar } \\
\text { traditional } \\
\text { arschitecture. }\end{array}$ & $\begin{array}{l}\text { The door to } \\
\text { access living } \\
\text { room and its top is } \\
\text { carved with the } \\
\text { simple pattern of } \\
\text { vegetation, such } \\
\text { as leaves, etc. The } \\
\text { other part has no } \\
\text { ornament, interior } \\
\text { and eksterior. }\end{array}$ & $\begin{array}{l}\text { The door to } \\
\text { access living } \\
\text { room and its top is } \\
\text { carved with the } \\
\text { simple pattern of } \\
\text { vegetation and } \\
\text { arabic calligraphy. } \\
\text { The other part has } \\
\text { no ornament, } \\
\text { unless the top of } \\
\text { Bubungan Tinggi } \\
\text { roof that has } \\
\text { Jamang (the } \\
\text { decoration of } \\
\text { wood carved on } \\
\text { the both top of } \\
\text { roof) with crown } \\
\text { motif. It also has } \\
\text { cross bar along } \\
\text { roof peak. }\end{array}$ & $\begin{array}{l}\text { The door to } \\
\text { access kitchen } \\
\text { and its top has } \\
\text { no ornament. } \\
\text { The other part } \\
\text { also has no } \\
\text { ornament, } \\
\text { interior and } \\
\text { eksterior. }\end{array}$ \\
\hline
\end{tabular}

Source: analysis. 


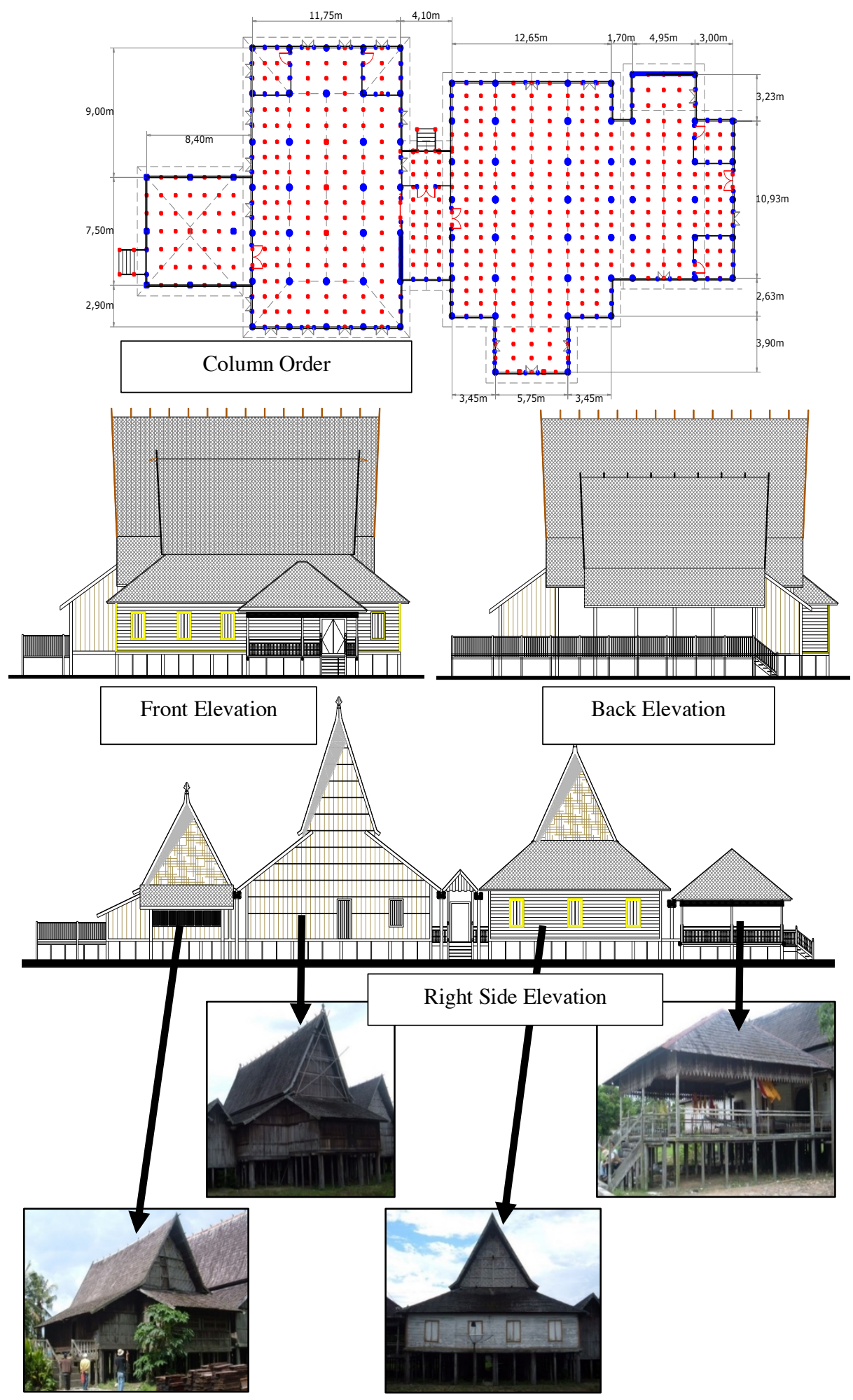

Fig. 2. Columns order and elevations of Astana Al-Nursari. 


\section{Astana Al-Nursari Describe The Basic Concept In Banjar Traditional Architecture}

From the comparation of research object and typology of Banjar traditional architecture by some variables (table 2), there are only a few similarity. It can be guessed that Astana AlNursari is not appropriate with Banjar traditional architecture. This statement is not true, if the analysis is deeper.

If we examined thoroughly, the room order pattern and the shape order pattern of Astana Al-Nursari and Banjar traditional architecture, has an extraordinary similarity.

Almost all type and samples of Banjar traditional architecture have same room order pattern. Number of the room about 4 to 5 rooms, ordered hierarchial from front side to back side, i.e.: pelatar/ terrace, penampik/ living room (kacil, tangah, basar), palidangan/ family room and anjung/ bedroom, and padapuran/ kitchen.

Astana Al-Nursari also has 4 rooms, i.e.: pendopo/ pelatar, living room \& multipurpose room/ penampik, living room/ palidangan and anjung/ bedroom, and padapuran/ kitchen.

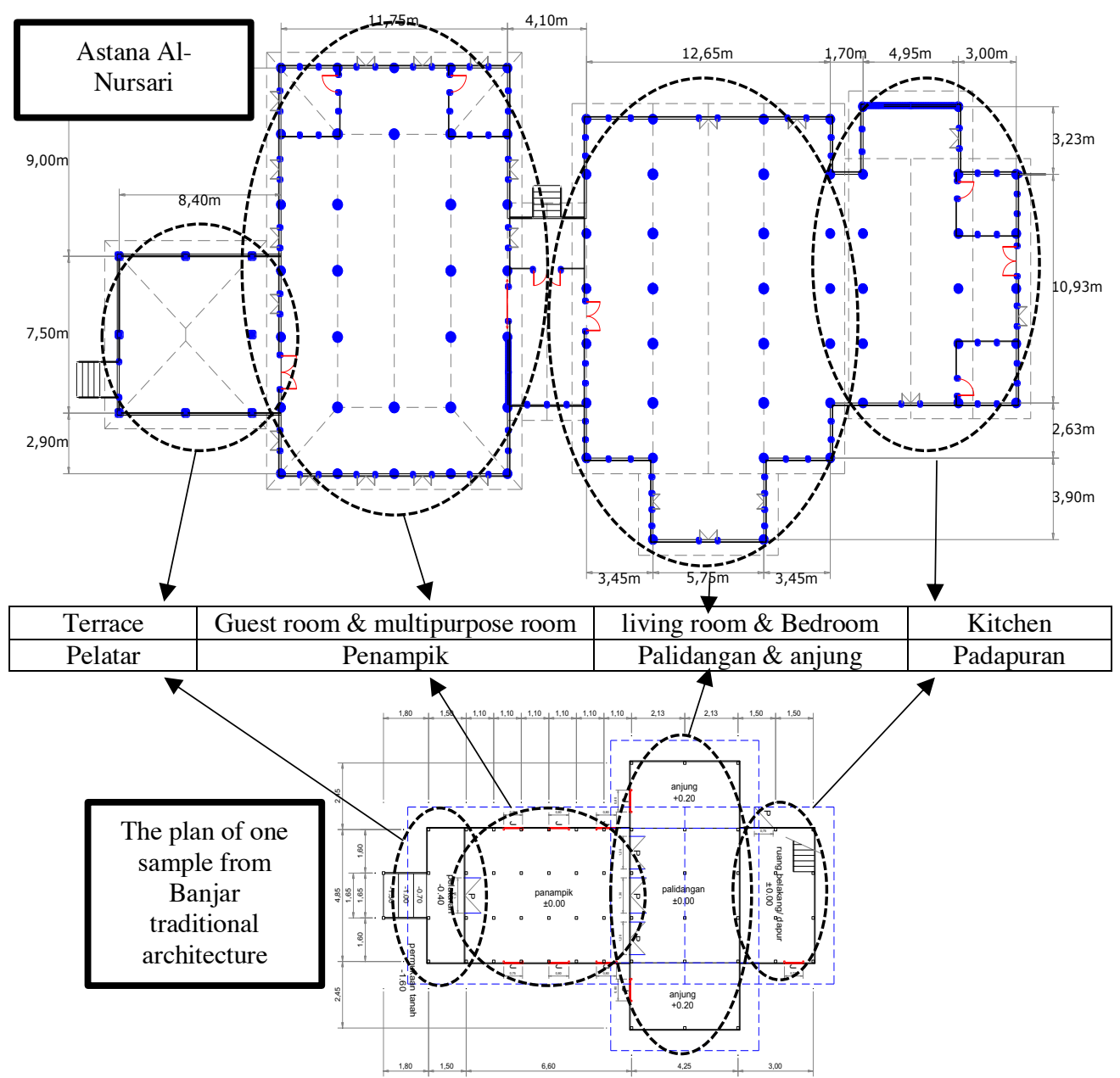

Fig. 3. The room order pattern and the shape order pattern. 
The shape of building (building envelope) in Banjar traditional architecture is reflected the priority of the covered room, which is higher tehe roof indicate higher the value of the room. The highest part is Bubungan Tinggi that covered palidangan (family room) and anjung (bedroom). The lower part is Palimasan that covered pendopo (pelatar).

Astana Al-Nursari has building shape that similar to the pattern in Banjar traditional architecture. Even the research object is divided to 4 mass, every mass is reflected the room hierarchy that is covered. It is precisely same with Banjar traditional architecture. Mass 3 that is covered palidangan and anjung has the highest roof. The lowest is pendopo/ pelatar.

The sketch below show the similarity of the shape.

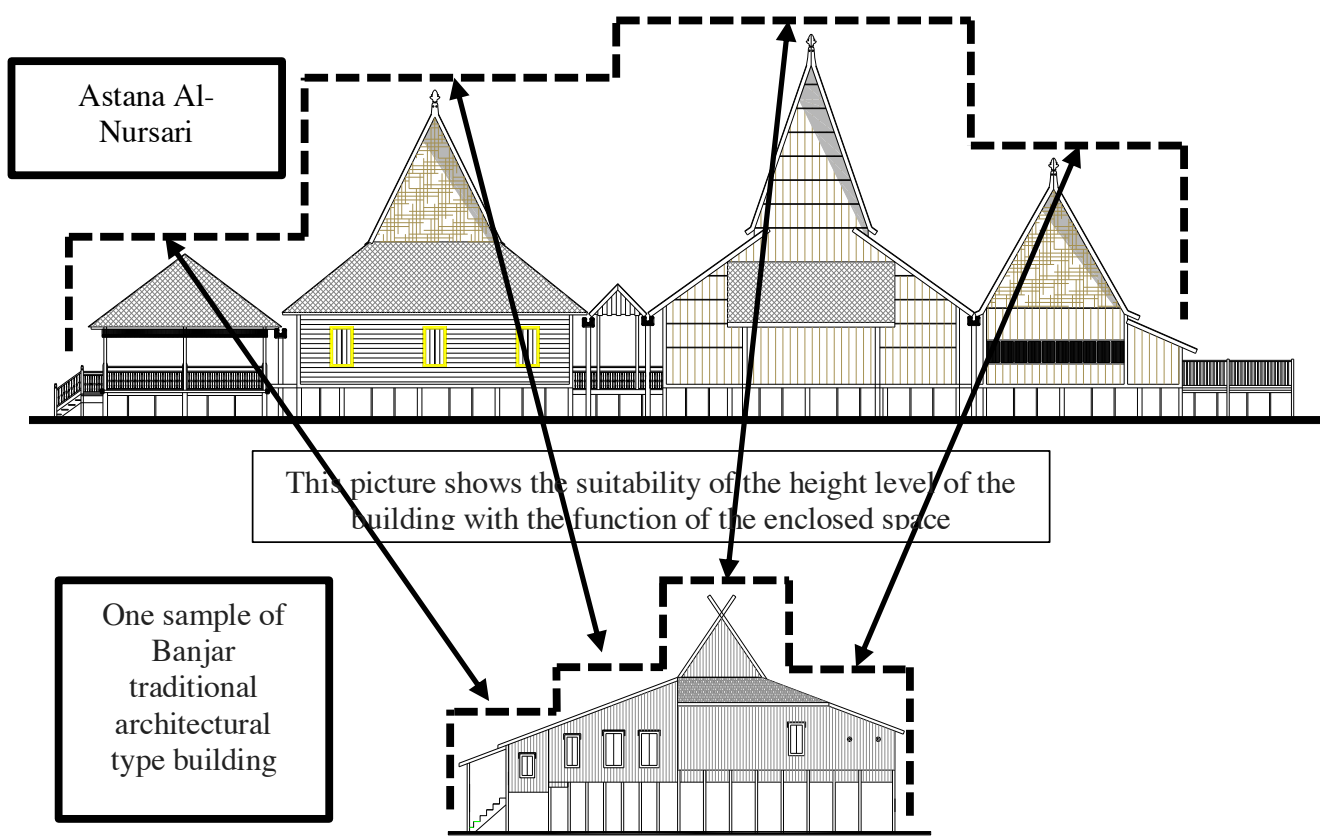

Fig. 4. The relationship between the philosophy of form and the space it covered.

The others part that are have similarity are: the number of windows, where in ruang keluarga/ panampik/ multipurpose room has most widely windows. Palidangan and anjung has a few windows. Meanwhile, pelatar and pendopo are not covered by wall.

\section{Conclusion}

Banjar traditional architecture can be applicated flexibly, and it is not defend to such determined proportion or ratio. Tinggi.

The dominant shape of Banjar traditional architecture is tapered roof of Bubungan

The similar aspects are: building material that is almost a whole from ulin wood (iron wood); stage structure; the main column/ pole is the long pole without connection from ground to ringbalk or roof; wooden boardthat is installed vertically.

The number and order pattern of windows is adjusted to the room function. The public and semi publid rooms have lots of windows, but the private room has a few windows.

The orientation of Banjar traditional building is not directed to the specific points of the compass, but it is directed perpendicular to river channel. 
Astana Al-Nursari is different with any type of Banjar traditional architecture. The shape is formed by type of Palimasan and Bubungan Tinggi which is combined in such a way, even though both of them has similar design concept.

Astana Al-Nursari has the same type of space and architecture as Banjar traditional architecture, consisting of 4 spatial chambers, namely: pelatar / pendopo (front), penampik / living room / multipurpose, palidangan / family room and anjung, and the kitchen (on the back).

The roof height on Astana Al-Nursari has the same concept with the roof on the traditional architecture of Banjar, where the highest roof is on the palidangan and anjung. The lowest is on the pelatar / pendopo.

The shape of the roof reflects the function of space in it, where the shape of Palimasan reflects the public function and the High Ridge shape reflects the private function. This can be seen from the pendopo which is open public space roofed Palimasan, while the family room and kitchen roofed Bubungan Tinggi. While panampik (the reception and multipurpose hall) which is semi public (between public and private) the roof is a combination of Palimasan and Bubungan Tinggi.

The number of openings / windows also indicates the public or private level of the building, where a very public pendopo with no walls, a semi-public and semi-public panampik (reception room) is enclosed by walls with numerous windows. While the family room and kitchen which is the private space have a few windows.

In relation to this research, for the future it is advisable: first, the need for more in-depth research on Astana Al-Nursari, such as structural systems, and others.

Secondly, Astana Al-Nursari is in the Kutaringin Sultanate complex, where there are also several other historic buildings, such as the Kyai Gede mosque. These buildings require extensive documentation and follow-up research.

And the formulation of typology of Banjar traditional architecture which has been based on samples of Banjar merchant's house, needs to be developed by examining the palace buildings that are related to the sultanate and Banjar culture, such as Astana Al-Nursari.

\section{Reference}

1. Bondan, Amir Hasan. 1953. Suluh Sedjarah Kalimantan. Banjarmasin : Penerbit Padjar.

2. Budihardjo, Eko. 1994. Percikan Masalah Arsitektur, Perumahan, Perkotaan. Gadjah Mada University Press.

3. Daud, Alfani. 1997. Islam dan Masyarakat Banjar. Jakarta : PT.Raja Grafindo Persada.

4. Huzairin, M. Deddy. 2002. Rumah Tradisional Banjar di Kampung Banua Anyar Banjarmasin. Penelitian dana mandiri.

5. Huzairin, M. Deddy. 2004. Inventarisasi Data Arsitektur Tradisional Banjar di Kawasan Bersejarah Sungai Jingah Banjarmasin. Penelitian didanai oleh Self Development Project Funding, HEDS JICA.

6. Huzairin, M. Deddy. 2004. Peningkatan Vitalitas Wisata Budaya di Kawasan Kuin Banjarmasin. Penelitian didanai oleh Program SP4.

7. Huzairin, M. Deddy. 2006. Tipologi dan Morfologi Arsitektur Tradisional Banjar di Banjarmasin Utara. Penelitian didanai oleh Program Penelitian Dosen Muda DP2M Ditjen Dikti. 
8. Huzairin, M. Deddy. 2009. Pedoman Standar Struktur dan Konstruksi Rumah Kayu pada Tanah Rawa didasarkan pada Kajian terhadap Arsitektur Tradisional Banjar. Penelitian didanai oleh Program Penelitian Hibah Bersaing Ditjen Dikti.

9. Koentjaraningrat. 1988. Manusia dan Kebudayaan di Indonesia. Jakarta : Djambatan.

10. Pemprop Kal-Sel. 2003. Sejarah Banjar. Banjarmasin. Pemerintah Provinsi Kalimantan Selatan.

11. Rapoport, Amos. 1969. House, Form, and Culture. New York : McGraw Hill.

12. Ras, J.J. 1968. Hikajat Bandjar, A Study in Malay Historiography. The Hague: Martinus Nijhoff.

13. Saleh, M. Idwar. et.al. 1977. Sejarah Daerah Kalimantan Selatan. Dirjen Kebudayaan. Banjarmasin : Proyek Penelitian dan Pencatatan Kebudayaan Daerah.

14. Saleh, M. Idwar. 1970. Banjarmasih.

15. Saleh, M. Idwar. 1983. Sekelumit Mengenai Rumah-rumah Tradisional Banjar (makalah seminar). Banjarmasin : Dinas PU Dati I Kal-Sel.

16. Sellato, Bernard. 1989. Naga dan Burung Enggang, Kalimantan-Sarawak- SabahBrunei. Jakarta: Elf Aquitaine Indonesie.

17. Syafrullah, M. 2004. Objek Pelestarian Warisan Budaya di Daerah Kalimantan Selatan. Disampaikan di Banjarmasin pada acara ceramah Bangunan Warisan Budaya di Daerah Kal-Sel 14 Desember 2004.

18. Seman, Syamsiar dan Irhamna. 2001. Arsitektur Tradisional Banjar Kalimantan Selatan. Banjarmasin. IAI Daerah Kal-Sel.

19. Tim Peneliti Arsitektur UNLAM. 2006. Tipologi dan Morfologi Arsitektur Tradisional Bakumpai di Marabahan. Penelitian didanai oleh Pemerintah Kabupaten Barito Kuala.

20. - --------. 1995. Pembinaan Budaya dalam Lingkungan Keluarga Daerah Kalimantan Selatan. Depdikbud. Banjarmasin : Proyek Pengkajian dan Pembinaan Nilai-Nilai Budaya Daerah Kalimantan Selatan. 